RISK MANAGEMENT. RISK COMMUNICATION

UDC 613.956: 616.1-02: 614.72

DOI: $10.21668 /$ health.risk/2018.3.14.eng

online

\title{
HYGIENIC ASSESSMENT OF MEASURES AIMED AT RISKS REDUCTION AND HEALTH PRESERVATION FOR CHILDREN IN SECONDARY SCHOOLS
}

\author{
V.V. Vasilyev ${ }^{1,2,3}$, M.V. Perekusikhin ${ }^{4}$ \\ ${ }^{1}$ Penza State University, 40 Krasnaya Str., Penza, 440026, Russian Federation \\ ${ }^{2}$ Penza Institute for Doctors' Advanced Training, a brunch of Russian Medical Academy for Continuous Occupational \\ Training, the Russian Public Healthcare Ministry, 8a Stasova Str., Penza, 440060, Russian Federation \\ ${ }^{3}$ N.N. Burdenko's Penza Regional Clinical Hospital, 28 Lermontova Str., Penza, 440026, Russian Federation \\ ${ }^{4}$ Federal Service for Surveillance over Consumer Rights Protection and Human Well-being, Penza Regional Office, \\ 35 Lermontova Str., Penza, 440026, Russian Federation
}

We questioned 1,064 school students from 5-11 grades and 720 parents of schoolchildren from 1-4 grades and assessed health of 2,512 children and teenagers via comparative examination performed in two secondary schools with similar sanitary-epidemiologic situation in them but different preventive activities accomplished and different medical care provided. The results we obtained via questioning and examination revealed that school children's health is preserved and improved due to targeted development of preventive activities and medical care, better nutrition in school, an increase in physical activities, and a growth in number of children who wish to pursue health-preserving behavior patterns. When a prevention and rehabilitation unit was established in a school it allowed to improve medical care and achieve a substantial decrease in morbidity among school children, first of all, with respiratory organs diseases which were a basic reason for absence from classes. Most children $(77.5 \%)$ who were made healthier or recovered in school had suffered from respiratory organs diseases.

Improvement of preventive activities aimed at creating health culture and attitudes towards healthy life style had positive influence on children's motivation and formation of such behavior stereotypes that helped to preserve their health. It was confirmed by questioning results as well as by lower levels of common and primary morbidity and better physical development. Share of practically healthy school students without any risk factors (the 1st health group) increased from $5.61 \%$ in 2009 to $8.54 \%$ in 2017; share of school students who were in the 2 nd health group (had functional deviations or ran risks of chronic pathology development) decreased from 86.28 to $83.98 \%$ ( $p<0.05)$.

Key words: preventive activities, medical care, school, school children, health, questioning.

Educational organizations are a priority part of schoolchildren environment and they can frequently cause health risks for them. The primary reasons here are them being not compliant with sanitary and epidemiologic requirements and standards in terms of their territory and buildings, organization of educational process [1-3] and nu- trition $[4,5]$, physical activities [6, 7], and medical support [8-12]. Educational process is becoming more intense and it causes risk-associated health disorders among schoolchildren [13]. Social and economic factors also exert negative influence on children's health as they determine their lifestyle and form health-preserving culture, healthy life-

(C) Vasilyev V.V., Perekusikhin M.V., 2018

Valery V. Vasilyev - Doctor of Medicine, Professor at Department for Hygiene, Public health and Public Health Care (e-mail: vvv1755@yandex.ru; tel.: +7(909)316-01-97).

Mikhail V. Perekusikhin - Supervisor (e-mail: sanepid@ sura.ru; tel.: +7 (8412) 55-26-06). 
styles, and children's leisure activities [14].

The necessity to manage schoolchildren's health risks led to development of recommendations on updating preventive activities and medical support for children and teenagers within scientific systems of knowledge [15, 16]. Issues of healthy lifestyle formation and unified preventive space in educational organizations have been revised [17, 18]. But still, there is not enough research that focuses on analyzing implementation practices related to preventive and health-improving activities and it predetermined the performance of the present research.

Our research goal was to assess results of long-term activities aimed at improvement of prevention work and medical support in educational organizations.

Data and methods. We performed our research in Penza and chose two comprehensive secondary schools as our research objects; the school No. 74 was a test one, and the school No. 68 was a reference one. We examined sanitary-hygienic parameters of intra-school environment and analyzed nutrition that schoolchildren received. We assessed activities accomplished by a prevention and rehabilitation unit in the test school; examined educational process conditions and health of children who attended 1-11 forms. our samplings included 1,136 and 1,376 school students correspondingly.

Both schools were located close to each other (420 meters from one to another) in the same city district (a dormitory area) with the same ecological conditions; both schools were built according to a typical building project. Nutrition units in both school were modernized in 2008 within the frameworks of a federal experimental project. Comparative hygienic assessment of the schools was performed taking into account all the specifications fixed in sanitary-epidemiologic requirements.

Prevention work aimed at improvement of schoolchildren's health has been accomplished since 2006 in the school No. 74, as opposed to the school No. 68. We questioned parents of elementary school pupils and parents of schoolchildren who attended 5-11 forms. We analyzed 366 questionnaires filled in by parents and 430 questionnaires filled in by school students who attended the school No. 74 (70\% of the total schoolchildren number). We also analyzed 354 questionnaires filled in by parents and 634 questionnaires filled in by schoolchildren who attended the school No. 68 (71.8\% of the total schoolchildren number). Actual nutrition received by schoolchildren was analyzed via examining two-week autumn (2017) and spring (2018) menus that included breakfast and lunch.

We assessed schoolchildren's health. The results were statistically processed with conventional techniques.

Results and discussion. Parameters of microclimate, electric and magnetic fields strength inside classrooms were measured in 2018; the results revealed there were only insignificant differences between the schools and all the parameters corresponded to standards in both of them.

Daylight factor in classrooms amounted to $6.99 \pm 0.82$ in the school No. $74 ; 2.55 \pm 0.76$, in the school No. 68 ( $\mathrm{p}<0.05)$.

Noise level in the corridors, gymnasium, canteen, and technology classes of the school No. 74 was within 51.4-80.5 decibels, and in IT classrooms, within 43.1-45.7 decibels; in the school No. 68, within 58.9-82.1 and 47.8-48.2 decibels correspondingly.

We didn't reveal any significant discrepancies in adverse substances concentrations in classrooms between the compared schools. Microbe contamination of the air also didn't differ significantly as the total microbe quantity ranged from 174 to 1,100 per $1 \mathrm{~m}^{3}$ (497.5 on average) in the school No.74; from 300 to 1,200 per $1 \mathrm{~m}^{3}$ (650 on average) in the school No. 68. School furniture didn't conform to height and age standards in $27.8 \%$ cases in the school No. 74 ; and in $53 \%$, in the school No. 68 ( $\mathrm{p}$ We detected that nutrition rations provided for elementary school pupils (1-4 forms) corresponded to this age group and deviated from recommended ones only slightly. Actual food value was $4.5 \%$ higher than the standard in the test school. Proteins, fats, and carbohydrates contents were $3.7,5.6$ and $2.7 \%$ higher, their ratio was $1: 1.1: 4.3$. Actual food value of nutrition ration provided in the reference school was $6.4 \%$ lower than the standard, proteins, fats, and hydrocarbons contents being 6.6, 3.8, and $4.1 \%$ lower correspondingly; macronutrient ratio was 1:1.1:4.8.

Most children (73.8 and 81.2\%; $\mathrm{p}<0.05)$ received such nutrition in their families that couldn't be called healthy. Ratio of basic food components (proteins, fats, and carbohydrates) in daily rations amounted to $1: 1.3: 5.5$ and $1: 1.4: 5.9$ in the compared groups correspondingly. Unbalanced daily rations as per ratios of basic food components were accompanied with excessive fats and carbohydrates consumption and overall prevalence of fats and carbohydrates in rations.

Preventive work accomplished in the school No. 74 had two basic lines, namely organi- 
zation of medical support for schoolchildren directly in school; targeted formation of knowledge and skills related to pursuing a healthy lifestyle.

In 2006 in the school No. 74 conventional medical support for schoolchildren was supplemented with an innovative prevention and rehabilitation unit (PRU). The PRU target was to implement preventive and health-improving activities among schoolchildren, and to improve health of everybody who needed it without any breaks in their educational process. An expected outcome would be a decrease in morbidity among children. Schoolchildren can receive physiotherapy and other health-improving procedures in the PRU when they are prescribed by a physician; there are no breaks in the educational process. Schoolchildren can also visit a pediatrician and a dentist in the PRU. The unit functions all the year round, even during school vacations when health-improving camps are open for children.

The PRU is a structural unit of a medical organization that provides medical personnel for it and equips medical rooms with all the necessary medical devices. The PRU includes a pediatrician room, therapeutic physical training room, massage room, physiotherapy room, and a dentist room. The school was to provide rooms prepared for the PRU organization. The PRU as per its functions is a unit that provides medical support for schoolchildren. Its activities are harmonized with European approaches to school healthcare [7].

The PRU functioning in the school No. 74 fully corresponds to the requirements stated in the Order by the RF Public Healthcare Ministry issued on November 5, 2013, No. $822 \mathrm{n}$ "On approval of order for providing medical support to under-aged citizens, including the period of education in educational organizations"1. 10,119 schoolchildren attending the school No. 74 improved their health and received rehabilitation procedures over 2007 2017 (from 893 to 1,197 annually).

Children with musculoskeletal pathologies $(38.8 \%)$ and with respiratory organs diseases $(19.9 \%)$ prevailed among those who applied for medical aid to the PRU, improved their health, and received rehabilitation procedures. A number of children who needed to improve their health due to eye and its accessory apparatus diseases was sig- nificantly lower and amounted to $12.3 \%$. A share of children with nervous system diseases amounted to $11.9 \%$; with injuries, $9.1 \%$; digestive organs diseases, $4.1 \%$; other diseases, $3.9 \%$. Physiotherapeutic procedures accounted for more than a half of all the rehabilitation activities (54.3\%). Therapeutic physical training accounted for $29.6 \%$; health-improving massage and massotherapy, for $16.1 \%$

Types and structure of rehabilitation activities are determined by a diagnosis. Physiotherapeutic treatment is mostly applied to improve health of children with respiratory organs diseases and injuries (91.4\%). Ear and mastoid diseases and digestive organs diseases require only therapeutic procedures. Therapeutic physical training is applied in almost half of cases when musculoskeletal system diseases, as well as eye and its accessory apparatus diseases are diagnosed. Massage is the most laborconsuming medical procedure and it is applied much more rarely. It is most frequently applied in case of nervous system diseases.

Health-improving activities for children performed by the PRU in the school No. 74 in 2007-2017 gave the following results in terms of all the diseases. $27.6 \%$ out of 10,119 children treated by the PRU recovered; $71.5 \%$ improved their health; there were no changes in health of $0.9 \%$ children; there were no cases in which children's health deteriorated. The most recovered children were detected among children with respiratory organs diseases $(77.5 \%)$ and ear and mastoid diseases $(62.4 \%)$.

An increase in number of children who were included into the 1st health group to attend physical training (without any limitation) and a decrease in number of children with the 2nd and the 3rd health groups (children who run risks of chronic pathologies or who already suffer from them or have physical development disorders) also prove that the PRU activities are quite efficient. Thus, a number of children with the 1st health group in the school No. 74 increased from $86.1 \%$ in $2009-2010$ school year to $93.7 \%$ in $2017-2018$ school year $(p<0.05)$; accordingly, there was a decrease in number of children with the 2 nd and the 3rd health groups from 13.9 to $6.3 \%(\mathrm{p}>0.05)$. A decrease in acute morbidity among chil-

\footnotetext{
${ }^{1}$ On approval of order for providing medical support to under-aged citizens, including the period of education in educational organizations: The Order by the RF Public Healthcare Ministry dated November 5, 2013 No. 822n. Garant.RU: information and legal portal. Available at: https://www.garant.ru/products/ipo/prime/doc/70471454/ (date of visit March 25, 2018).
} 
dren (measured as a number of absence cases per 1 child) is another proof that the PRU activities are efficient. Absence due to acute morbidity decreased by $3.5 \%(\mathrm{p}>0.05)$. As for the reference school, a number of children with the 1st health group changed only slightly over the examined period, from $89.3 \%$ in $2009-2010$ to $90.2 \%$ in 2017-2018; absence increased by $1.9 \%(p>0.05)$.

Issues of health lifestyle formation have been solved in the school No. 74 through intersectoral partnership since 2008; as for the reference school, only conventional ways have been applied there.

Healthy lifestyle formation among children attending 1-11 forms is implemented with educational technologies created with the help of Ropotrabnazor experts and HEE teaching staff, as well as social, medical, and information technologies. First of all, application of multi-subject technologies allows to achieve better awareness about risk factors among children, patens, and school personnel; secondly, it provides motivation and creates conditions for healthy lifestyle formation; thirdly, it can help to develop and secure health-preserving behavioral skills in children and teenagers.

In order to increase physical activity of students, in 2008-2009 two gymnasiums, a swimming pool and a training ground near the school No. 74 were re-equipped.

We performed sociologic questioning among parents whose children attended 1-4 forms; the questioning revealed that almost all pupils ate cooked meals at school, $96.9 \%$ in the school No. 74 and $96.7 \%$ in the school No. $68.89 .3 \%$ of children attending the school No. 74 had a snack (fruit) between breakfast, lunch, and dinner; only $71.2 \%$ of those attending school No. 68 ( $p<0.001)$ did it. This difference is not caused by material wellbeing of a family as $78.4 \%$ of parents whose children attended the test school and $88.9 \%$ of parents whose children attended the reference school ( $\mathrm{p}<$ 0.05 ) considered their material well-being quite satisfactory. A share of children who consumed sweets and French fries between breakfast and lunch was higher in the reference school than in the test one, $70.5 \%$ against $58.7 \%$ correspondingly $(\mathrm{p}<0.01)$. Children who attend the school No. 74 much more rarely consume fast-food outside the school than children from the school No. 68, 27\% against $42.6 \%$ correspondingly $(\mathrm{p}<0.01)$. Therefore, four out of ten children attending the school No. 68 consume food that can hardly be called healthy and their eating habits are not healthpreserving ones.
The results of questioning performed among students attending 5-11 forms prove that children and teenagers from the test school are much more motivated to pursue a healthy lifestyle than their counterparts from the reference school (Table). Thus, a share of children with correct eating habits is authentically higher in the school No. 74 than in the school No. 68. But at the same time, only $32.2 \%$ of schoolchildren from the school No. 74 considered school meals to be good; $27.7 \%$ gave the same estimation in the school No. 68 (p > $0.05) .44 \%$ and $38 \%$ correspondingly considered school meals to be satisfactory ( $p>0.05$ ); $23,8 \%$ and $34,3 \%$ correspondingly thought them to be unsatisfactory $(\mathrm{p}<0.05)$. These rather low scores given to school meals by schoolchildren can be caused by incomplete provision of cooked meals that are not enough for every schoolchild; such a situation, in its turn, can exert negative influence on schoolchildren's health.

Table

Results of questioning performed among students attending 5-11 forms in the compared schools

\begin{tabular}{|l|c|c|c|}
\hline \multicolumn{1}{|c|}{ Students' answers } & $\begin{array}{c}\text { School } \\
\text { No. 74, } \\
\%\end{array}$ & $\begin{array}{c}\text { School } \\
\text { No. 68, }\end{array}$ & $p$ \\
\hline Have breakfast at home & 88,3 & 83,7 & 0,040 \\
\hline $\begin{array}{l}\text { Have second breakfast at } \\
\text { school }\end{array}$ & 57,9 & 35,1 & 0,000 \\
\hline $\begin{array}{l}\text { Have cooked meal for } \\
\text { lunch }\end{array}$ & 83,9 & 82,1 & 0,457 \\
\hline $\begin{array}{l}\text { Have dairy products eve- } \\
\text { ry day }\end{array}$ & 72,1 & 61,5 & 0,022 \\
\hline $\begin{array}{l}\text { Have meat products every } \\
\text { day }\end{array}$ & 80,0 & 71,6 & 0,002 \\
\hline Have fruit every day & 80,0 & 63,1 & 0,000 \\
\hline Eat fast-food & 55,3 & 59,8 & 0,130 \\
\hline Go to school on foot & 87,2 & 76,4 & 0,000 \\
\hline Do morning exercises & 33,5 & 25,4 & 0,005 \\
\hline Do sports & 67,8 & 62,9 & 0,117 \\
\hline $\begin{array}{l}\text { Walk on foot a day: more } \\
\text { than 2 km }\end{array}$ & 72,4 & 65,3 & 0,015 \\
\hline $\begin{array}{l}\text { Spend from 1 to 3 hours a } \\
\text { day working on a PC }\end{array}$ & 74,2 & 64,5 & 0,026 \\
\hline $\begin{array}{l}\text { Watch TV from 1 to 3 } \\
\text { hours a day }\end{array}$ & 86,9 & 87,1 & 1,00 \\
\hline $\begin{array}{l}\text { Night sleep lasts 8 hours } \\
\text { or more }\end{array}$ & 54,6 & 51,4 & 0,53 \\
\hline
\end{tabular}


More than a half of children do sports at sport clubs, 63.9 and $64.9 \%$ correspondingly; but only each fourth or fifth student does morning exercises, 21.8 and $24.3 \%$ correspondingly. And parents tend to overestimate physical activities of their children as 88.2 and $92.6 \%$ of them correspondingly consider them to be sufficient. Parents of children who attend the school No. 74 more frequently give a good example to their children showing them physical exercises and activity is useful for health than their counterparts whose children attend the school No. 68. But still, this obvious good example isn't in line with a share of children who do morning exercises.

Almost all schoolchildren attending both schools have a walk outdoors every day. But at the same time, it is rather alarming that children from the reference school break a daily regime as $19.8 \%$ of children sleep less than 8 hours at night. A share of such children in the test school is authentically lower. Uncontrolled TV watching and time spent at a PC is a reason for shorter sleep on weekdays. Thus, $8.1 \%$ and $5.9 \%$ of children from the school No. 74 watch TV or work on a PC for more than 3 hours correspondingly; these figures amount to 10.8 and $7.2 \%$ of children from the school No. 68 correspondingly.

Schoolchildren from the test school are more active physically than their counterparts from the reference school where respondents obviously tend to overestimate their daily physical activity. Meanwhile, $93.7 \%$ of respondents from the school No. 74 have the 1 st health group (without any riskfactors), and only $90.2 \%$ of children from the school No. 68 have the same health group. Besides, a share of children who go to school on foot or walk more $2 \mathrm{~km}$ a day is significantly higher in the test school.

Most children from the test school, and considerably fewer children from the reference school, believe their parents give them a good example how to pursue a healthy lifestyle. $95.1 \%$ of respondents from the school No. 74 think that a school should take active part in building skills of healthy behavior and healthy lifestyle in schoolchildren; only $80.4 \%$ of schoolchildren who attended the school No. 68 gave the same answer (p $<0.001$ ). Unsurprisingly, $93.7 \%$ of respondents from the test school think that creation of a healthy lifestyle is being accomplished quite actively in their school; only $67.3 \%$ of schoolchildren from the school No. 68 are of the same opinion (p < 0.001 ).
There was a question "How do you assess medical support provided for children in the school?"; parents gave the following answers to it: "good" was given by $64.2 \%$ in the school No. 74 and by $52.5 \%$ in the school No. 68 (p < 0.01$)$; "satisfactory", by 28.7 and $39.4 \%(p<0.01)$ correspondingly; "unsatisfactory", by 7.1 and $8.1 \%$ correspondingly. Students attending 5-11 forms gave other evaluation of medical support in their schools: "good" was given by 56.1 and $45.6 \%$ ( $\mathrm{p}=$ 0.001); "satisfactory", by 32.7 and $33.9 \%$; "unsatisfactory", by 11.2 and $20.5 \%(\mathrm{p}=0.005)$ correspondingly.

As for core values of life, family took the first place in the lists of respondents from both schools, $89.3 \%$ in the test school, and $85.9 \%$ in the reference one; students from the test school gave the second place to health $(77.2 \%)$ while their counterparts from the reference school to friends $(61.3 \%)$; the third place was given to friends $(66.2 \%)$ and health $(59.7 \%)$ correspondingly; the fourth place was given to education (62.4 and 49.8 $\%)$.

We analyzed the results of questioning performed among parents whose children attended 1-4 forms and 5-8 forms and can state that updating of prevention work aimed at creating health culture and a healthy lifestyle in schoolstudents had positive effects on their motivation and building of behavioral stereotypes that helped to preserve and improve their health. But still we should note that a great number of children don't have enough sleep, spend too much time at a PC, are not physically active, and don't have cooked meals at school. Although a share of such children is much lower in the test school than in the reference one, all these parameters of a lifestyle are in this case a field where prevention activities should be performed in future.

Morbidity among children was taken as a performance criterion for activities aimed at healthy lifestyle formation. In 2017 prevalence of diseases among children in the school No. 74 amounted to $1,353.2 \%$, that was lower than the same parameter among children in the school No. $68,1,524.6 \%$ o ( $\mathrm{p}<0.001)$. This discrepancy between overall morbidity levels was mostly due to different prevalence of respiratory organs diseases, $587.1 \%$ against $808.7 \%$ correspondingly ( $\mathrm{p}<$ 0.001). We also detected a significant discrepancy in primary morbidity levels among children from the schools under comparison, 640.8 and $854.3 \%$ o ( $\mathrm{p}<0.001$ ); this discrepancy was mostly due to higher morbidity with respiratory organs diseases, 
555.2 against $760.1 \%$ ( $\mathrm{p}<0.001)$. Schoolchildren who attend the school No. 74 suffer from respiratory organs diseases 1.36 times less frequently. We didn't detect any other significant discrepancies between the two schools as per other nosologies ( $p$ $>0.05$ ).

Assessment of schoolchildren's physical development performed in 1-4 forms revealed that a share of children with average height and body weight parameters (4-5 centile ranges) was practically the same, $34.9 \%$ in the test school, and $32.2 \%$ in the reference one. A share of children with physical development parameters being higher than average values (6-8 centile ranges) amounted to $41.4 \%$ and $40.3 \%$ correspondingly; lower than average values (1-3 centile ranges), $23.7 \%$ and $27.5 \%$ correspondingly. Distribution of children as per body mass index revealed that there were more children with optimal nutrition status in the school No. 74 than in the school No. 68, 55.5\% against $43.6 \%(p<0.05)$. Insufficient nutrition status was detected in $13.4 \%$ of children from the test school and in $15.0 \%$ of children from the reference one; the excessive nutrition status was detected in $31.1 \%$ and $41.4 \%$ of children correspondingly.

Compression force of a hand was higher in children from the test school than in children from the reference one. The examined parameter of a right hand amounted to $13.03 \mathrm{~kg}$ in the test school, and to $10.17 \mathrm{~kg}$, in the reference one $(\mathrm{p}<0.05)$. Compression force of a left hand amounted to 7.83 and $11.2 \mathrm{~kg}$ correspondingly $(\mathrm{p}<0.05)$. We also revealed that there was an authentic discrepancy in vital capacity of lungs in children from the compared schools, 1.431 in the school No. 74 against 1.291 in the school No. $68(\mathrm{p}<0.05)$.

Our assessment of adaptation capacities revealed that they were higher in children from the test school than in those from the reference one; satisfactory adaptation was detected in $15.3 \%$ and $12.8 \%$ correspondingly; strain in adaptation mechanisms, in 46.7 and $41.7 \%$; unsatisfactory adaptation, in 19.4 and $24.7 \%$; adaptation mechanisms failure, in 18.6 and $20.8 \%$ of children correspondingly.

A share of practically healthy children (the 1st health group) attending school No. 74 increased from $5.61 \%$ in 2009 to $8.54 \%$ in 2017 . A share of children with the 2 nd health group (children with functional deviations who run risks of chronic pathology development) decreased from $86.28 \%$ in 2009 to $83.98 \%$ in 2017 ( $p<0.05$ ). But at the same time there were only slight changes in a share of children who suffered from chronic pathologies at compensation stage and had the 3rd health group and a share of children who had the 4th health group and suffered from chronic diseases at subcompensation stage, from $7.28 \%$ to $6.25 \%$ and from $0.83 \%$ to $1.23 \%$ correspondingly.

We detected quite different trends in the school No. 68. Thus, a share of children with the 1 st and 2nd health group practically didn't change, $7.41 \%$ and $8.03 \% ; 81.84 \%$ and $81.75 \%$. A share of children with the 3rd health group increased from 7.06 to $8.82 \%(p<0.05)$, and a share of children with the 4 th health group increased from $0.72 \%$ to $4 \%$.

Conclusions. We performed comparative examination of two schools with the same sanitaryepidemiologic well-being but different preventive activities implemented and medical support provided in them; the examination included sociologic questioning and assessment of health of children who attended these two schools. The examination results revealed that targeted modernization of preventive activities and medical support, improvement of school meals, greater physical activity, and an increase in number of children with healthpreserving behavioral attitudes had positive effects on formation of schoolchildren's health. Positive changes have occurred in that school where preventive activities have been implemented for many years; first of all, they were changes in motivation and children's drive for health-preserving behavior.

Modernization of medical support via organization of a prevention and rehabilitation unit (PRU) in the school allowed to achieve a significant decrease in morbidity among schoolchildren, first of all, with respiratory organs diseases that were a basic reason for absence from classes. The greatest share of children who recovered after visiting the PRU had previously suffered from respiratory organs diseases $(77.5 \%)$.

Our questioning revealed the most significant risk factors that required development and implementation of preventive activities; the factors included nutrition behavior defects, incomplete provision of all the children with cooked meals, disorders in daily regime, and more than 3 hours spent at a PC. These and some other problems are more apparent in the reference school and require immediate attention.

Results of the research that generalized long-term experience in creating a unified prevention environment in a secondary school substantiated creating and implementing scientifically grounded recommendations in the region. 
Funding. The research was given any sponsor support.
Conflict of interest. The authors state there is no conflict of interest.

\section{References}

1. Mylnikova I.V. Gigienicheskaya otsenka vnutrishkol'noi sredy gorodskikh i sel'skikh obrazovatel'nykh uchrezhdenii [Hygienic assessment of intraschool environment in rural and urban secondary school institute ons]. Gigiena $i$ sanitariya, 2016, vol. 95, no. 12, pp. 1193-1197 (in Russian).

2. Haverinen-Shaughnessy U., Shaughnessy R. J., Cole E. C., Toyinbo O., Moschandreas D.J. An assessment of indoor environmental quality in schools and its association with health and performance. $\begin{array}{lllll}\text { Building and } & \text { Environment, } & \text { 2015, } & \text { vol. }\end{array}$ (part 1), pp. 35-40. DOI: 10.1016/j.buildenv.2015.03.006

3. Valina S.L., Ustinova O.Yu., Maklakova O.A., Ivashova Yu.A. Sravnitel'naya otsenka funktsional'nogo sostoyaniya serdechno-sosudistoi i vegetativnoi nervnoi sistemy u detei doshkol'nykh obrazovatel'nykh organizatsii obshcherazvivayushchei napravlennosti s razlichnoi napolnya-emost'yu grupp [Comparative evaluation of the functional state of the cardiovascular and the vegetative nervous system in children of general preschool educational establishments with various representation of groups]. Fundamental'nye issledovaniya, 2015, no. 1-7, pp. 1334-1338 (in Russian).

3. Hrebtova A.Yu., Goreva E.A., Petrenko A.V. Stereotipy pitaniya detei v shkol'nykh kollektivakh [Stereotypes of the children nutrition at school associations]. Uchenye zapiski universiteta im. P.F. Lesgafta, 2015, no. 4, pp. 190-196 (in Russian).

4. Esaulenko I.E., Nastausheva T.L., Zhdanova O.A., Minakova O.V., Logvinova I.I., Ippolitova L.I. Regulyarnoe pitanie $\mathrm{v}$ shkole kak faktor fizicheskogo razvitiya detei i podrostkov: rezul'taty kogortnogo issledovaniya [Regular meals at school as a factor of physical development of children and adolescents: results of a cohort study]. Voprosy sovremennoi pediatrii, 2016, vol. 15, no. 4, pp. 364-370 (in Russian).

5. Gvozdareva O.V. Rezul'taty issledovaniya vliyaniya dvigatel'noi aktivnosti na zdorov'e shkol'nikov Gorno-Altaiska [Results of investigation of influence of motor performance on the health of schoolchildren of Gorno-Altaisk]. Zdorov'e naseleniya i sreda obitaniya, 2017, vol. 288, no. 3, pp. 47-50 (in Russian).

6. Van Kann D.H.H., De Vries S.I., Schipperijn J., De Vries N.K., Jansen J.M.W., Kremers S.P., Choolyard J. Characteristics, Physical Activity, and Sedentary Behavior: Combining GPS and Accelerometry. Journal of School Health, 2016, vol. 86, no. 12, pp. 913-921.

7. Sokolova S.B., Kuchma V.R. Kontseptsiya otsenki kachestva meditsinskoi pomoshchi obuchayushchimsya $\mathrm{v}$ obrazovatel'nykh organizatsiyakh [Framework for quality of the health care in educational organization]. Zdorov'e naseleniya i sreda obitaniya, 2016, vol. 281, no. 8, pp. 8-12 (in Russian).

8. Kuchma V. R., Makarova A. Yu., Rapoport I. K. Sostoyanie meditsinskogo obespecheniya detei $\mathrm{v}$ obrazovatel'nykh organizatsiyakh [Status health care for children in educational institutions]. Voprosy shkol'noi i universitetskoi meditsiny i zdorov'ya, 2017, no. 2, pp. 37-45 (in Russian).

9. Baranov A.A., Kuchma V.R., Anufrieva E.V., Sokolova S.V., Skoblina N.A., Virabova A.N., Makarova A.Yu., Trofimenko E.V., Kvilinskii P.N., Sapunova N.O. Otsenka kachestva okazaniya meditsinskoi pomoshchi obuchayushchimsya $\mathrm{v}$ obrazovatel'nykh organizatsiyakh [Quality Evaluation of Healthcare Services in Schools]. Vestnik Rossiiskoi akademii meditsinskikh nauk, 2017, vol. 72, no. 3, pp. 180-194 (in Russian). DOI: 10.15690/vramn830

10. Michael S.L, Merlo C.L., Basch C.E., Wentzel K.R, Wechler H. Health and Academics Critical Connections: Health and Academics. Journal of School Health, 2015, vol. 85, no. 11, pp. 740-758. DOI: 10.1111/josh.12309 
11. Hunt P., Barrison L., Telljohann S.K, Mazyck D.A. Whole School Approach Collaborative Development of School Health Policies, Processes, and Practices. Journal of School Health, 2015, vol. 85, no. 11, pp. 802-809. DOI: 10.1111/josh.12305

12. Ustinova O.Yu., Valina S.L., Kobyakova O.A., Nikiforova N.V., Alekseeva A.V. Obosnovanie optimal'noi napolnyaemosti grupp doshkol'nykh obrazovatel'nykh organizatsii obshcherazvivayushchei napravlennosti [Rationale for the optimal group occupancy in preschool educational institutions of general enrichment orientation]. Gigiena i sanitariya, 2016, vol. 95, no 1, pp. 57-63 (in Russian).

13. Elgar F.J., Pförtner T.-K., Moor I., De Clercq B., Stevens G.W., Currie C. Socioeconomic inequalities in adolescent health 2002-2010: A time-series analysis of 34 countries participating in the Health Behaviour in School-Aged Children study. Lancet, 2015, vol. 385 (9982), pp. 2088-2095. DOI: 10.1016/S0140-6736 (14) 61460-4

14. Sukharev A.G., Stan V.V., Ignatova L.F. Rol' obrazovatel'noi organizatsii v formirovanii u uchashchikhsya motivatsii k zdorov'yu i zdorovomu obrazu zhizni [The role of educational organizations in the development of students" motivation to health and healthy lifestyle]. Voprosy shkol'noi $i$ universitetskoi meditsiny i zdorov'ya, 2016, no. 2, pp. 32-35 (in Russian).

15. Kovtun O.P., Anufrieva E.V., Nozhkina N.V., Malyamova L.N. Shkol'naya meditsina: analiz dostignutykh rezul'tatov i poisk novykh reshenii [School medicine: analysis of achieved results and search for new solutions]. Vestnik ural'skoi meditsinskoi akademicheskoi nauki, 2018, vol. 15, no. 1, pp. 136-145 (in Russian). DOI: 10.22138/2500-0918-2018-15-1-136-145

16. Kuchma V.R. Formirovanie zdorovogo obraza zhizni detei i edinogo profilakticheskogo prostranstva $\mathrm{v}$ obrazovatel'nykh organizatsiyakh: problemy i puti resheniya [Hygiene of children and teenagers in the formation of health of the nation]. Gigiena $i$ sanitariya, 2015, vol. 94, no. 6, pp. 20-25 (in Russian).

17. Stiefel L., Prescott M.P., Schwartz A.E. School Wellness Programs: Magnitude and Distribution in New York City Public Schools. Journal of School Health, 2017, vol. 87, no. 1, pp. 3-11. DOI: 10.1111/josh. 12463

18. Zahnd W.E, Smith T., Ryherd S.J., Cleer M., Rogers V., Steward D.E. Implementing a Nutrition and Physical Activity Curriculum in Head Start Through an Academic-Community Partnership. Journal of School Health, 2017, vol. 87, no. 6, pp. 465-473. DOI: 10.1111/josh.12515.

Vasilyev V.V., Perekusikhin M.V. Hygienic assessment of measures aimed at risks reduction and health preservation for children in secondary schools. Health Risk Analysis, 2018, no. 3, pp. 128-135. DOI: 10.21668/health.risk/2018.3.14.eng

Received: 28.06 .2018

Accepted: 06.08.2018

Published: 30.09.2018 